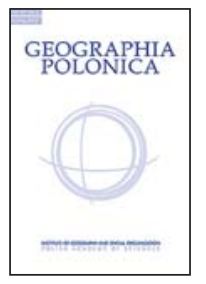

\title{
FROM SOCIALIST ICONS TO POST-SOCIALIST ATTRACTIONS: ICONICITY OF SOCIALIST HERITAGE IN CENTRAL AND EASTERN EUROPE
}

\author{
Nikola Naumov ${ }^{1}$ (D) Adi Weidenfeld ${ }^{2}$ \\ ${ }^{1}$ Department of Events, Tourism \& Hospitality, Faculty of Business \& Law \\ University of Northampton, Waterside Campus \\ Learning Hub Building, Room LH201 \\ NN1 5PH, University Drive, Northampton: United Kingdom \\ e-mail: nick.naumov@northampton.ac.uk \\ ${ }^{2}$ School of Marketing \& Management, Faculty of Business \& Law \\ Coventry University, Jaguar Building \\ CV1 1FB, Priory Street, Coventry: United Kingdom \\ e-mail: adi.weidenfeld@coventry.ac.uk
}

\begin{abstract}
The 1989 fall of the Iron Curtain marked the beginning of new economic, socio-cultural and political realities for the former socialist states in Central and Eastern Europe. Along with the economic restructuring from statecentralised to market economy, democratisation and liberalisation initiated a transformation of the socialist urban space, which was characterised by the changing role of its iconic landmarks. This conceptual paper examines these post-1989 changes, which range between the removal of these landmarks and their transition into market led iconic and flagship attractions. The paper identifies the changing role of tourism from a topbottom orchestrated to a market led activity, which explains the transformation of some of these landmarks. It introduces a new framework for studying this process by suggesting that iconisation, de-iconisation and re-iconisation processes are interrelated to other strategies and approaches to the transition of the socialist urban landscape into a western market economy. The paper identifies avenues for further research and provides some recommendations for improving the management of similar processes.
\end{abstract}

\section{Key words}

iconicity $\bullet$ socialism $\bullet$ heritage $\bullet$ tourism $\bullet$ visitor attractions $\bullet$ Central and Eastern Europe

\section{Introduction}

Central and Eastern Europe is a region often explored through the lenses of its turbulent and rather problematic recent past. The division of Europe into 'West' and 'East' symbolically marked by the Iron Curtain after the Second World War, and more specifically, 
the allegiance of Eastern Europe to the Soviet Union and the principles of Marxism-Leninism, had a huge influence over various aspects of urban space and urban iconography of the countries part of the former socialist Eastern Bloc (Aman 1992; Murzyn 2008). The end of the Second World War in 1945 marked the beginning of many new strategies for spatial planning driven by aspirations for modernisation of infrastructure and economic development (see for example, Hamilton, Dimitrovska Andrews, \& Pichler-Milanovic 2005).

However, socialism was much more an ideological and political construction than an outcome of modernity. An important aspect of the socialist political leadership was the introduction of Marxism - Leninism not only as a form of governance but also as a radical political ideology with strictly fixed norms of how socialism would be understood and interpreted into political, economic and socio-cultural dimensions (Verdery 1996). An integral part of this transformation was devoted to cultural heritage and more specifically, representation and interpretation of the past. According to Fowkes (2002: 65) 'building socialism involved changing people's minds and view of history, not just the material conditions of their lives'. This process involved quite diverse methods, including ideological monumentality of urban space and state-supported domestic tourism activities (see for example, Light, Young \& Czepczyński 2009). The key notion of socialist monumentality and architecture was their importance as markers of a collective memory and an identity as well as a part of the state-sanctioned political propaganda to ascribe meanings and values (Till 2004; Vukov 2006). The erection of monuments and sites was a symbolic act of proclaiming a sense of uniformity, which would eventually lead to an allegiance to the socialist dogma (Groys 2003: 113). Monuments of glorified socialist leaders and 'iconic' mega structures (e.g. Palace of Culture and Science in Warsaw or the Palace of the Parliament in Bucharest) not only dominated the cityscapes of major cities such as Warsaw, Riga, Bucharest and
Sofia but also covered the streets of almost every single town and village across Eastern Europe. These purposefully-built landmarks together with museums and sites of industrial achievements were the main foci of statefunded domestic travel (Gorsuch 2003; Gorsuch \& Koenker 2006).

Between 1989 and 1991, and especially after the collapse of the Soviet Union in 1991, many of the former socialist countries started to adopt new initiatives and models, based on the capitalist and democratic principles of Western Europe (Giatzidis 2002; Kiglics 2007). An important aspect of the transition concerned the previously glorified 'iconic' mega structures, largely regarded as the symbols of the pre-1989 political regime as well as the erection of new western style modern landmark buildings. The changes to urban landscapes involved the demolition/removal of socialist monuments from central squares and streets and evidence of this could be best seen in Banska Bystrica in Slovakia (Bitusikova 1998), Warsaw (Czarniawska 2002), Mostar in Bosnia-Herzegovina (Grodach 2002), Leipzig (Coles 2003), Riga (Sparitis 2003) and Berlin (Cochrane 2006; Till 2005). However, despite making considerable efforts and forming new spatial strategies, the (re)creation of the new postsocialist urban space remains a long and difficult process. The problematic collective memory of socialism, nostalgic evocation to the socialist past and subjective interpretations of socialist heritage might explain why many controversial socialist icons still dominate the urban landscape of many post-socialist cities.

A substantial part of the academic scholarship has focused on the processes of political and economic transition after 1989 in Eastern Europe and more specifically on the regime change (Cox 2011; Giatzidis 2002), the demise of the Soviet Union (Kramer 2011), the shift from state-centralised to market-economy and the subsequent processes of economic stagnation and financial constraints (e.g. Kiglics 2007; Linz \& Stepan 1996). Studies analysing the changing 
policies, markets and development of tourism in transition (e.g. Bachvarov 1997, 2006; Baláž \& Williams 2000; Hall 1991, 2008; Jaakson 1996; Marciszewska 2006; Müller \& Więckowski 2018) have also emerged but academic literature on the relationship between tourism, heritage and visitor attractions in socialist and post-socialist contexts including communism and subsequent transition is still young. Whereas some studies focus on the (re)construction of the postsocialist built environment and the (re)creation of urban space have also emerged (e.g. Crowley \& Reed 2002; Czepczyński 2008; Diener \& Hagen 2013), the transformation of socialist iconicity and socialist heritage sites into new market-led visitor attractions remains overlooked.

This conceptual paper seeks to address this gap by examining this process in the context of iconicity and flagshipness of visitor attractions (Weidenfeld 2010; Weidenfeld et al. 2016) in post-socialist and former communist countries in Eastern Europe. First, it explores the post-1989 transformation of 'memorial landscapes' (Dwyer \& Alderman 2008) and examines the importance of urban space and politics of collective memory in the process. Second, the role of tourism in the (re)emergence of former socialist landmarks is explained and explored in major socialist heritage sites in Eastern Europe. Finally, it suggests new avenues for future research and implications for managing the transition of post socialist heritage sites into new market led major visitor attractions.

\section{Iconicity and flagshipness}

Based on their impact and perceived image major visitor attractions are classified into iconic and/or flagship. They are often used as 'tools for economic development and as catalysts of urban regeneration, social change, and rebranding in urban and rural settings' (Weidenfeld 2010: 851). 'Flagshipness' is primarily examined through the lenses of marketing, advertising, economic development and income generation. It often characterises purposely built attractions such as EuroDisney and Coca Cola London Eye (Swarbrooke 2002) which try to maximise their visitor numbers. Iconicity, however, emphasises distinctive symbolism, which is inextricably linked to culture, heritage and perceived authenticity. Major attractions with high levels of iconicity are defined as iconic attractions, which provide a 'mental construct' and are perceived as a symbol and a subject of admiration by visitors and residents alike, primarily as a result of being often perceived as an authentic representation of their regional local culture/heritage (Weidenfeld et al. 2016).

Whereas 'flagshipness' is the outcome of the ability to generate a substantial appeal resulting in drawing masses of visitors and stimulate economic development, both directly and indirectly, 'iconicity' concerns a major attraction's contribution to the overall destination image beyond its premises. Iconic attractions may be restricted to a small number of annual visitors if any, such as the Houses of Parliament and the Buckingham Palace in London or the Tokyo Imperial Palace. They may neither draw a large number of visitors nor be considered economically viable, but increase the overall numbers of visitors to their destination region for their physical presence and inspiring image (Weidenfeld et al. 2016).

Iconicity and flagshipness are not mutually exclusive as major attractions can be characterised by high levels of both when drawing a larger number of visitor compared to others and having an outstanding impact on drawing visitors to the entire region. Attractions can also lose their iconic status (de-iconisation) and regain it (re-iconisation) along time (Weidenfeld et al. 2016). This section examines whether and how the discourses of heritage and memory underlie the interpretation, management and development of socialist iconic landmarks. It also explores the role of tourism and that of iconicity, iconisation, de and re-iconisation in implementing these post 1989 transitional processes. 


\section{Iconicity socialist monumentality: socialist and post-socialist perspectives}

Central to the principles of socialism was the relationship between urbanism, monumentality, and national identity (Czepczyński 2008; Verdery 1996). Socialist urban landscapes in Central and Eastern Europe were largely influenced by the Soviet spatial planning from the early 1920s such as Lenin's "Plan for Monumental Propaganda" (Lodder 1993). The urban landscapes were a mixture of 'grand designs' - large monuments, grand scale civic spaces, spacious city parks, and parade squares (Adams 2008; Czepczyński 2008; Murzyn 2008; Szelenyi 1996). Gigantic memorial monuments and pantheons dedicated to socialist heroes (e.g. Marx, Engels, Lenin, Stalin), victory of the Soviet Army over Nazi Germany, and the unknown soldiers were common landmarks across socialist boulevards and central districts. This hyperbolic 'monumentalism' dominated the urban space of all Soviet satellites - from Central and Eastern Europe to Eurasia - and was ideologically driven to transmit certain political expressions, social meanings and identities (Crowley \& Reid 2002). Their outstanding visibility and architectural design were often linked to their city or regions, which constitute the understudied socialist iconicity of the built environment.

\section{Iconicity of socialist heritage}

Urban iconography and spatial planning were 'symbolic texts that reflect social, economic, and political relationships of power and resistance through their aesthetics, function, layout and scale' (Diener \& Hagen 2013: 490). Moreover, urban spaces were used as symbolic arenas where the leading socialist parties actively demonstrated their political vision for societal development emphasizing the key achievements of the socialist doctrine (Bell 1999). Socialist urbanism, however, was much more than a symbolic manifestation of political power. As noted by Crowley and Reid (2002: 16), the adoption of socialist ideology involved a "radical break with the past". A reformulation of history, identity and social relations was needed in order to "display a distinctive national past and articulate an exclusive understanding of a cultural political community" (Till 2004: 351). According to Czepczyński (2008: 63), one of the main purposes was "the will to change society by or through, architecture, design and cultural landscape". These political aspirations are manifested with the mega structures built in many socialist states before 1989 such as the Palace of Parliament in Bucharest (Sima 2017), the Palace of Culture and Science in Warsaw (Derek 2018) and the Buzludzha Monument near Kazanlak in Bulgaria (Poria, Ivanov \& Webster 2014). Such buildings were part of the 'branding through flagship' strategy (Ashworth 2009: 15), which had the ultimate goal of symbolising the achievements of socialism and symbolise the political power of the regime. Similar to other buildings and structures they were distinctive features of 'the socialist city' and widely regarded as representations of heritage, culture and society as well as their city or regions and therefore they are classified as 'icons' or iconic landmarks of the socialist built environment (Aman 1992; Murzyn 2008).

Iconicity of socialist heritage through the lenses of the social representation theory and the work of Serge Moscovici (1988, 2000) can be related to the processes of 'collective meaning-making' (Höijer 2011: 3). This process focuses on phenomena, which are subjects to conflicts, ideological interpretations, emotions, feelings and divergent memories. Moscovici's 'social representations' relate to cultural and/or symbolic material objects that represent certain religious beliefs, political ideas and the interrelationship between them. This can be applied to socialist heritage and their political importance because socialist iconicity represents manifestations of a 'collective meaning-making' and crafts a certain symbolic and ideological narrative 
of heritage as a representation of socialist 'imagined communities' (Anderson 1991).

The iconicity of socialist heritage was also supported by the development of statesupported domestic tourism. Iconic buildings, heritage sites, historical places and places associated with socialist industrial achievements were popular among tour operators (and therefore among visitors) and pivotal to the way socialist regimes perceived and operated 'turizm' - state-funded excursions provided to form a sense of uniformity, inspire patriotism and improves one's social and cultural attachment to the nation (Gorsuch \& Koenker 2006; Koenker 2013; Rosenbaum 2015). Socialist tourism was developed as a state priority and heritage was an important instrument promoted to demonstrate the glory of the socialist past (Grandits \& Taylor 2010; Murzyn 2008). It included governments' subsidised domestic visits to museums, historical places, monuments and other socialist memorials in order to build national identity and enhance the sense of belonging of local societies. Places such as the mausoleums of Lenin in Moscow and Georgi Dimitrov in Bulgaria, the birthplaces of Nicolae Ceauşescu in Romania and Josip Tito in Yugoslavia, were among the most visited sites, constructed and promoted as a part of the communist ideology (Gorsuch \& Koenker 2006; Light 2013; Light \& Young 2010; Light, Young \& Czepczyński 2009; Vukov \& Toncheva 2006).

The classic definition of visitor attractions as natural or man-made features and objects with a special appeal to tourists (Swarbrooke 2002) is problematic to apply to the pre-1989 tourism context in the former socialist states. Socialist landmarks, museums and heritage sites were relatively under-developed as visitor attractions or as leisure consumption, recreation and entertainment facilities for visitors. Their top down orchestrated popularity among visitors cannot be considered genuine. Socialist top down iconicity, however, can characterise these sites. Their images were 'imposed' by the public authorities as images of certain ideological symbols and values, that were embedded into selected sites. In fact, most of the socialist iconicity was based around monumentality, museums and heritage sites and their primary role was to serve domestic propaganda and provide settings for facilitating patriotic education. Flagshipness in terms of attracting a large number of visitors to their premises or beyond was irrelevant but this has changed with the gradual changes following the fall of communism and the emergence of capitalist market economy in former communist and socialist countries.

\section{Transformation from socialist to market-led iconicity}

The appeal of the (former) socialist landmarks has changed after the fall of the socialist doctrine and the emerging democratic changes within the Eastern Bloc. After 1989, the Eastern Bloc countries were very often considered as being in 'transition', which refers to 'situations where change is not smooth and stepwise, but rather dramatic, rapid and fundamental' (Müller 2018: 1). This was the case with the majority of the post-socialist states and their shift from central economy to a market-based economy (Agnew 2000). However, as Martens \& Rothmans (2005: 1136) argue, any transition period should be explained not only as a political and economic process, but also as 'a gradual, continuous process of societal change where the structural character of society (or a complex sub-system of society) transforms'. In the case of post-socialist Eastern Europe, this process has been mainly characterised by the (re)emergence of national identity and the rejection of socialist ties. After the break-up of the socialist dogma, the communist regimes were no longer supported. Instead, they were reconstructed, reproduced or totally abandoned (Light 2000a). This transition was largely based on the desire of post-socialist countries to construct new democratic and capitalist societies which itself involved the rejection of their socialist past, culture and ideologies (Grodach 2002; Munasinghe 2005; Young \& Light 2001; 
Young \& Kaczmarek 2008). New emerging strategies have been developed to demonstrate their modern, cosmopolitan and European identity. The newly-formed states were turning to the West as an attempt to legitimize their new governments and even those with fewer historical ties such (e.g. Romania and the Baltic States) demonstrated a willingness to embrace the political and economic orthodoxy of Western Europe (Light 2000a; Sparitis 2003; Young \& Light 2001). Tourism has played a crucial role in these processes, particularly in the emergence of new branding strategies and tourism products (de Rosa, Bocci \& Dryjanska 2017; Kaneva 2012). Instrumental to these strategies has been the European Capital of Culture status, which was successfully awarded to Krakow (2000), Sibiu (2008), Vilnius (2009), Pecs (2010), Tallinn (2012) and Riga (2014) - Central and Eastern European cities which have undergone radical transformation after 1989 (see Hughes, Allen \& Wasik 2003). A good example of a (re)branding strategy is the case of Bucharest and the re-appearance of the myth of 'Little Paris'. Pre-socialist heritage and in particular, the influence of French architecture, have been promoted and much emphasis has been put on the ancient history and culture of Romania (Dumbraveanu 2011; Kaneva \& Popescu 2011).

The fall of socialism also initiated radical transformations of urban space, including a broader restructuring of capital cities, spatial reconfiguration and displacement/ destruction of the socialist past (see for example, Andrusz, Harloe \& Szelenyi 1996; Stanilov 2007). The new political agenda has contributed to various impacts related to the cultural landscapes of post-socialist cities in terms of how places have (re)emerged and how identities, images of the past and collective memory have been (re)constructed (Bartetzky 2006; Czepczyński 2010; Rátz, Smith \& Michalkó 2008). These processes have affected the role of monumentality in urban landscapes and its transition from iconic socialism into capitalist market economy where tourism continued to play a pivotal role.

\section{Transitional strategies for managing post-socialist heritage}

Different approaches suggest the interpretations of socialist heritage across the former Eastern Europe (Light \& Young 2010). Young \& Kaczmarek (2008) differentiate between de-communization, Europeanization and the re-emergence of previously glorified icons. De-communization is the physical removal of socialist heritage and Europeanisation/ Westernisation is the emphasis on past links with Western Europe while rejecting associations with the 'East' and the socialist past' (Young \& Kaczmarek 2008). The re-emergence of previously glorified icons and symbols is the so-called return to the pre-socialist Golden Era, which were mirrored in its typical architecture of buildings of that time. For example, the Cathedral of Christ the Saviour in Moscow, demolished by the Bolsheviks in 1931 to create space for the never completed Palace of the Soviets, which has been resurrected in 2000 and become Russia's most famous geographical post-1989 symbol for the failed Communist endeavour (Sidorov 2000).

According to Forest \& Johnson (2002), socialist heritage in the post-1989 era has been referred to as glorified, disavowed and/ or contested by local stakeholders. Glorification takes place when socialist heritage is preserved by the wide public as a way of recognition and remembrance (e.g. Victory Park in Moscow). Disavowed sites (or disavowal of sites) are considered to be remains of socialism and have been removed from the urban space as a result of political changes (e.g. the removal of Lenin Monument in central Sofia or the displacement of Felix Dzierżyński's statue in Warsaw). Contested sites represent various conflicts and tensions usually related to social, cultural and political aspirations. They tend to be neither glorified nor removed from urban landscapes e.g. the Lenin Mausoleum in Moscow (Forest \& Johnson 2002). These approaches to socialist heritage can be related to Balockaite's (2012) three strategies for the post-1989 spatial reconfiguration 
of urban spaces including spatial isolation, spatial reframing and narrative reframing. Spatial isolation exemplifies the displacement of socialist heritage and its separation from its original cultural, political and social contexts. Grūtas Park, a sculpture-garden exposition of Soviet-era monuments in Lithuania, which once occupied central areas, streets and pedestrian squares (see Lankauskas 2006), is an example of the removal of disavowed heritage and 'de-communization' process. It has been recently developed as a collection museum of displaced monuments and as such, it is often visited by both domestic and international tourists.

The example of Grūtas Park also refers to the spatial reframing and involves the 'museumification' of socialist heritage and is best exemplified with the emergence of communism-themed museums across Eastern Europe such as Museum of Genocide Victims in Vilnius, Museum of Crimes and Victims of Communism in Bratislava and the House of Terror in Budapest. They can also be related to the aforementioned glorification of socialist heritage. Narrative reframing refers to the changing interpretation and the discourses of memory. For example, the perception of the Palace of Parliament in Bucharest, a pre-1989 socialist icon has shifted towards an emphasis on its unique architecture and distinctive visibility (Otto 2008). It can be related to Europeanisation/ Westernisation and the re-emergence of previously glorified icons and symbols (Young \& Kaczmarek 2008) as well as with contested (i.e. contestation) sites, which remain in their original location while being re-interpreted and re-negotiated by various stakeholders (Forest \& Johnson 2002).

Despite the relevance of the abovementioned conceptual approaches to the reconfiguration of post-socialist urban space, they refer to socialist heritage in general rather than to distinctive iconic landmarks. While many socialist attributes and symbols can be easily removed, torn-down or even destroyed, the gigantic and iconic landmarks are difficult or impossible to be physically removed let alone symbolically erased from a nation's collective memory. Here, the role of tourism as a major player in the transformation of the significance and meaningfulness of urban and cultural landscapes is examined through the lenses of a more recent market-led tourism iconisation, deiconisation and re-iconisation strategies and processes (Weidenfeld 2010), whereby both bottom-up market led, and top-down powers interact.

\section{The role of tourism in the transition of socialist landmarks}

It is therefore suggested that strategies of spatial reconfiguration (Balockaite 2012), Young \& Kaczmarek's (2008) processes and Forest \& Johnson's (2002) approaches to interpret and manage socialist heritage are interrelated and how tourism's new role in these processes engendered new market led processes of (de)iconisation and reiconisation. This can be used as a new conceptual framework for identifying and studying the transition of socialist built heritage to a western market economy in general and that of iconic landmarks and the role of tourism in post1989 countries in particular. More specifically, this paper suggests that iconisation, deiconisation and re-iconisation can explain the transition of iconic landmarks from socialism into a market economy.

\section{Iconisation, de-iconisation and re-iconisation of socialist landmarks}

Iconisation refers to the processes which make products saleable by imbuing them with desirable images of persons, cities, regions and cultures (Weidenfeld et al. 2010: 191). Visitor attractions are often iconised when they become distinctive regional brands and are often used in destination marketing, place branding and advertising of their regions. Therefore, in tourism, iconisation refers to the process whereby sites, structures and buildings are perceived as symbols 
of their city or a region among tourists and residents. Such icons tend to be characterised by outstanding visibility and unique architecture (Weidenfeld et al. 2016). In the pre-1989 socialist context, iconisation cannot be perceived in the market economy context but as a top down glorification of socialist heritage and the symbolic development of heritage sites as political icons of identity. Socialist iconisation therefore refers to the processes of national identity construction whereby socialist monumentality played an instrumental role for imposing an allegiance to the socialist 'imagined communities' (Anderson 1991). In this context, iconisation has no marketing/commercial value and primarily adheres to the ideological manifestation of the pre-1989 regimes. In terms of transformation, post 1989 transformation of landmarks in an emerging market economy characterised new iconisation processes of outstanding 'ordinary' and 'non-socialist' buildings and sites such as the Fernsehturm, the television tower in central Berlin (Weidenfeld et al. 2016) and the aviation museum in Belgrade.

De-iconisation is the 'decline process in terms of loss of iconicity' and refers to the loss of appeal of a given structure or visitor attraction (Wendenfeld et al. 2010: 194). In the context of socialist built heritage, deiconisation is the symbolic loss of meaningful of the image previously attached to socialist monumentality. This refers to Balockaite's (2012) spatial isolation and often occurs in cases of 'de-communization' (Young \& Kaczmarek, 2008) - the physical removal of socialist heritage and/or its displacement to remote and/or hidden areas. For example, many of the monuments now displayed in the Museum of Socialist Art in Sofia, Bulgaria were kept in storehouses or small and remote countryside museums for many years until the museum opened its doors in 2011 (Naumov 2018). This approach can be related to the demolition or symbolic destruction of socialist monumentality in countries, which opposed the socialist regime before 1989 such as Romania, Hungary, Poland and the Baltic States (see Diener \& Hagen 2013; Light 2000a; Sparitis 2003). The removal of the statue of Felix Dzierżyński in Warsaw, for example, was enthusiastically welcomed by the crowds and regarded as 'breaking the chains with the past' (Dudek 2005) while in Ukraine most of the previously glorified socialist monuments were removed after the introduction of the de-communization laws in 2015 (Kozyrska 2016).

Another example of de-iconisation is the complete ignorance of socialist monumentality in urban spaces. This primarily refers to what Forest and Johnston (2002) describe as 'contested heritage' and is often the case in countries with uncertain/contested politics of memory where there is no authorised, state sanctioned discourse about how to deal with the material legacy of the recent past and more importantly, how to interpret and present it to the new generations (Vukov 2008). One such case is the Buzludzha Momument near Kazanlak in Bulgaria. Unveiled in 1981 to mark the 1300-centenary of the Bulgarian state, Buzludzha is a gigantic megalith constructed on the top of Buzludzha Peak to symbolise the birth of socialism in Bulgaria on the same place in 1891 but also to symbolically show the 'path to enlightenment' to the socialist followers. Glorified and cherished before 1989 and albeit its iconic socialist heritage value, the house-memorial has been since vandalised, abandoned and left to destruction. Despite its huge potential to become a 'flagship' attraction, drawing more visitors to its premises than its neighbouring attractions, Buzludzha remains a dilapidated site without restoration project in the horizon.

De-iconisation also involves spatial reframing and re-contextualisation of socialist history. In this context, de-iconisation can be intentional and planned by public authorities in order to serve certain educational or economic purposes. In socialist heritage context, this primarily refers to the commercialisation of socialist heritage, its manufacturing as a tourism product and most importantly, as a commercial attraction for tourist consumption. This is best exemplified 
with the development of communist-heritage tourism. As Ivanov (2009) explains, this is distinctive form of niche tourism based on the tourists' interest to learn more about socialism, socialist architecture and socialist heritage (see also, Adie, Amore \& Hall 2017; Ivanov 2009; Light 2000b). A good example of a communist-heritage visitor attraction is Memento Park, a must visit visitor attraction near Budapest which tells the history of Hungarian socialism in Hungary entertainingly. It consists of a statue park (42 statues of socialist leaders), tourist and educational centres as well as a thematic and impressive architectural composition that resembles the reality of socialist architecture (McKenzie 2011). Another example is the city of Gori (Georgia), the birthplace of Joseph Stalin. The city has been a very popular destination since the opening of the Stalin Museum including the replacement of the patriotic and ideological pre-1989 narrative with a more engaging story about Stalin's life. The de-iconisation of socialism, driven by public authorities and the anticipated tourism demand, has contributed to the place (re)branding of Gori and its emergence as a destination for anyone interested in the history of socialism (see Beatley 2017).

Re-iconisation reflects 'changes in the political, historical and environmental settings of the development of place attachment over time' and can be defined as 'an attempt to regain a major attraction's iconicity by rebranding their image in line with that of their destination image' (Weidenfeld et al. 2010: 194). In the context of socialist heritage, this primarily refers to the post 1989 aspirations of local societies for place (re)branding, which have been implemented through deliberate marketing emphasising architecture and beauty while ignoring any ideological, historical or political aspects (Kaneva 2012; Kaneva \& Popescu 2011).

The aforementioned approaches to the transition of socialist built heritage including iconisation, de-iconisation and re-iconisation are not mutually exclusive. They can take place simultaneously or subsequently.
Socialist iconic landmarks can be subject to spatial isolation, special reframing and de-iconisation but, driven by the post-1989 economic and social changes, they can be subject of narrative reframing and eventually re-iconised. A representative example is the city of Warsaw in Poland and the role of the Palace of Culture and Science in the post-1989 re-branding of the city of Warsaw as a growing financial and trade centre and at the beginning of its westernisation moving towards EU membership (Pyzik 2015). In the post-1989 era, Warsaw's branding has been radically changed with new initiatives such as 'Royal Route', 'Visit Chopin in Warsaw', 'In the footsteps of Maria Skłodowska-Curie' and 'Traces of John Paul II' and 'Socialist realism in Warsaw' (see for example, de Rosa \& Dryjanska 2017). The Palace of Culture and Science has been de-iconised in the early years of transition followed by reiconisation as a cultural and tourist image of the city especially amongst the younger post 1989 generations (Pyzik 2015; Weidenfeld et al. 2016). Its re-iconisation continues nowadays as a major visitor attraction including a guided tour of the building, a museum and a conference and exhibition venue. It also provides commercial and office spaces for business use (Pyzik 2015). The Palace is an example of both narrative reframing and spatial reframing for offering and attracting visitors for commercial, leisure, entertainment, conferencing and tourism.

Another notable example is the case of Budapest and its post-socialist revival. As demonstrated in the study of Ratz, Smith \& Michalko (2008), Budapest has undergone a cultural revival since 1989 transforming 'old spaces into new places'. In addition to the above-mentioned Memento Park, historic districts and spaces have been given a new meaning and status (such as the World Heritage Designation) and new tourist routes and itineraries have also been introduced (e.g. the Cultural Avenue project).

Iconisation, de-iconisation and re-iconisation can be also explained from a social representation perspective. As Moscovici (2000) 
argues, social representation is dynamic and constantly generates changes in meanings and attitudes towards different phenomena. Iconisation, de-iconisation and re-iconisation processes reflect changes in the representation of socialist heritage over time and are shaped by wider political and socio-cultural 'transitions'. Cases such as Budapest and Warsaw are examples of how iconicity and social representations are interrelated to each other as both depend on how the societies absorb and react to political changes and whether or not they remain engaged and associated with the previously glorified icons of socialism.

\section{Conclusion}

The transition period of many former socialist countries since 1989 included a transformation of its built heritage. One of its most prominent changes was the transformation of its iconic landmarks. These included physical and perceptual ongoing changes which were shaped by political, ideological and economic change since 1989. This conceptual paper examined these post-1989 changes which vary between the removal of these landmarks and their transition into market led iconic and flagship attractions. The paper identified the particular importance of the changing role of tourism from a top bottom orchestrated to a market led activity, which explains the transformation of some of these landmarks.

The socialist built heritage has been a subject of many different approaches, interpretations and development management policies (Balockaite 2012, Young \& Kaczmarek 2008; Forest \& Johnson 2002), which provide a conceptual understanding for the ongoing transition towards a more western market economy through iconisation of entirely new icons, de-iconisation of contested or controversial icons and the re-iconisation of some of them embedding with new national or western new or 'revived' icons from the past (Fig. 1).

The post-1989 economic restructuring and the 'Europeanisation' of the former socialist countries have changed the role of tourism
Socialist Iconicity of Sites Communism

\section{Visited sites}
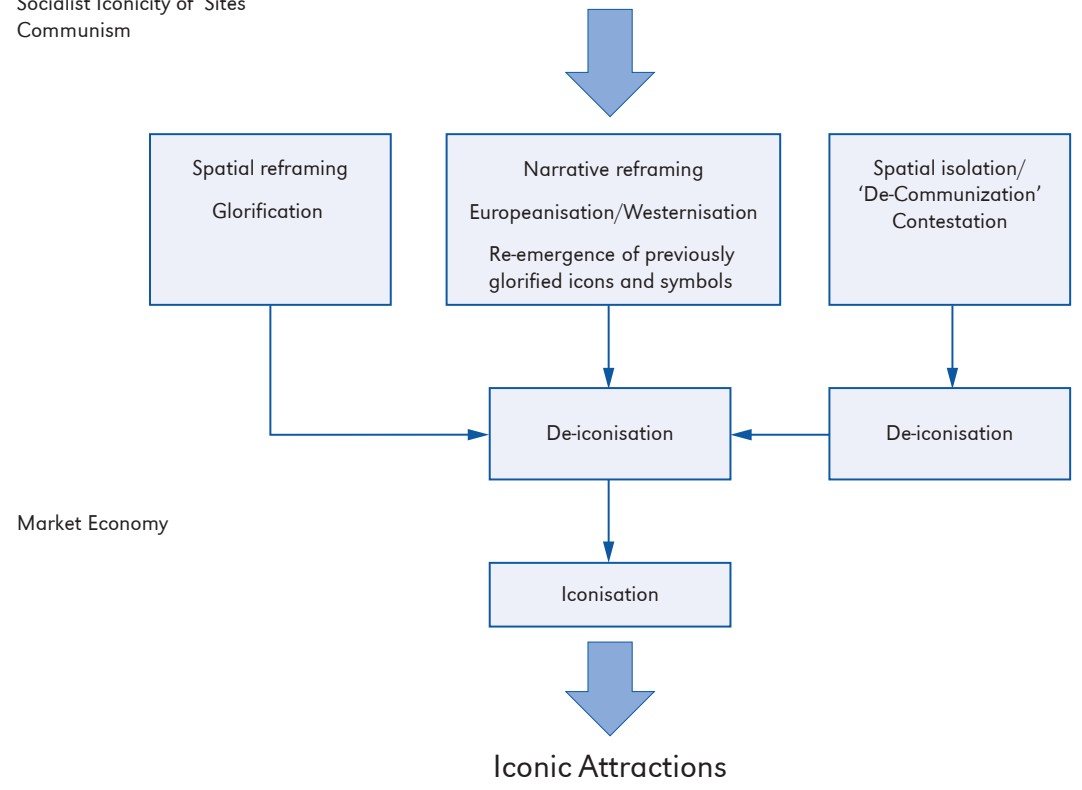

Figure 1. Transition of socialist iconic visited landmarks into iconic attractions 
in these countries from a top down ideological and political tool to a market driven activity, which explains the transformation of socialist landmarks and icons into visitor attractions. This conceptual paper has contributed to the academic literature of socialist and post-socialist urban geography, tourism and visitor attractions management by providing a framework to understand and study the emergence and changing importance of socialist iconicity. It suggests different approaches to dealing with the socialist past and socialist heritage in Eastern Europe, which are also germane to other countries where tourism as a market led activity is growing such as Cuba and Belarus and where tourism is already an emerging industry and is likely to transform iconic religious and political landmarks into iconic visitor attractions e.g. Saudi Arabia. It may be also relevant to countries, where tourism is likely to emerge in the future e.g. North Korea, where A particular importance should be placed on the potential use of this framework in managing these sites, which may help in identifying potential processes to each landmark and consider

\section{References}

Adams J., 2008. Monumentality in urban design: The case of Russia. Eurasian Geography and Economics, vol. 49, no. 3, pp. 280-303.

Adie B., Amore A., Hall C., 2017. Urban tourism and urban socialist and communist heritage: Beyond tragedy and farce? International Journal of Tourism Cities, vol. 3, no. 3, pp. 291-304.

Agnew J., 2000. How many Europes? The changed terms of debate in the 1990s over EU enlargement into Central and Eastern Europe and the acceptance of uneven development in Europe's future [in:] D. Hall \& D. Danta (eds.), Europe Goes East: EU Enlargement, Diversity and Uncertainty, London: The Stationery Office, pp.45-54.

Aman A., 1992. Architecture and ideology in Eastern Europe during the Stalin Era. An Aspect of Cold War history. New York: The MIT Press. its future image and the implications for its usage.

Further research is needed in the changing role of socialist iconicity in the post-socialist era from a multidisciplinary perspective. In particular, further research should explore the role of socialist heritage within the social representation of post-socialist cities such as Warsaw, Budapest or Sofia. Following Moscovici (2000), social representations in this context include symbolism, images, collective memory, meanings and attitudes attached to cultural heritage, urban space and (socialist) monumentality (see also de Rosa 2013). Anthropological and sociological perspectives on socialist heritage could explore the changing narrative of symbolic representation and more specifically, the interplay between collective memory, national identity and brand representation.

Editors' note:

Unless otherwise stated, the sources of tables and figures are the authors', on the basis of their own research.

Anderson B., 1991. Imagined communities: Reflections on the origins and spread of nationalism. London: Verso.

Andrusz G., Harloe M., Szelenyl I., 1996. Cities after socialism: Urban and regional change and conflict in post-socialist societies. Malden, MA: Blackwell.

AsHWORTH G., 2009. The Instruments of place branding: How is it done?. European Spatial Research and Policy, vol. 16, no 1, pp. 9-22.

BachVarov M., 1997. End of the model? Tourism in post-communist Bulgaria. Tourism Management, vol.18, no. 1, pp. 43-50.

Bachvarov M., 2006. Tourism in Bulgaria [in:] D. Hall, M. Smith \& B. Marciszewska (eds.), Tourism in the New Europe: The challenges and opportunities of EU enlargement. Wallingford: CABI Publishing, pp. 241-255. 
BalÁž V., Williams A., 2000. Tourism in transition: Economic change in Central Europe. London \& New York: I.B. Tauris.

BALOCKAITE R., 2012. Coping with the unwanted past in planned socialist towns: Visaginas, Tychy, and Nowa Huta. Slovo, vol. 24, no. 1, pp. 41-57.

Bartetzky A., 2006. Changes in the political iconography of East Central European capitals after 1989 (Berlin, Warsaw, Prague, Bratislava). International Review of Sociology vol. 16, no. 2, pp. 451-469.

BeAtLEy M., 2017. Stalin museum: The creepy attraction in Georgia that still worships the communist leader like a god. The Independent, https://www.independent.co.uk/travel/europe/ stalin-museum-gori-georgia-open-joseph-communist-leader-dictator-death-mask-a8065256. html [21 Nov 2017].

BeLL J., 1999. Redefining national identity in Uzbekistan: Symbolic tensions in Tashkent's official public landscape. Ecumene, vol. 6, no. 2, pp. 184-213.

BITUSIKOVA A., 1998. Transformations of a city centre in the light of ideologies: The case of Banska Bystrica, Slovakia. International Journal of Urban and Regional Research, vol. 22, no. 4, pp. 614-622.

Cochrane A., 2006. Making up meanings in a capital city: Power, memory and monuments in Berlin. European Urban and Regional Studies, vol.13, no. 1, pp. 5-24.

Coles T., 2003. Urban tourism, place promotion and economic restructuring: The case of postsocialist Leipzig. Tourism Geographies vol. 5, no. 2, pp. 190-219.

Cox T., 2011. 1989 and the Transformations in Eastern Europe, Europe-Asia Studies vol.63, no.9, pp. 1529-1534.

Crowley D., ReID S., 2002. Socialist spaces: Sites of everyday life in the Eastern Bloc [in:] D. Crowley, S.E. Reid (eds.), Socialist spaces: Sites of everyday life in the Eastern Bloc. Oxford: Berg, pp. 1-23.

Czarniawska B., 2002. Remembering while forgetting: The role of automorphism in city management in Warsaw. Public Administration Review, vol. 62, pp. 163-73.

CZEPCZYŃSKI M., 2008. Cultural landscapes of post-socialist cities: Representation of powers and needs. Aldershot: Ashgate Publishing.
CZEPCZYŃSKI M., 2010. Interpreting post-socialist icons: From pride and hate towards disappearance and/or assimilation. Human Geographies, vol. 4, no.1, pp. 67-78.

DE ROSA A.S., 2013. Social representations in the 'social arena'. New York and London: Routledge.

DE Rosa A.S., DryjansKa L., 2017. Visiting Warsaw for the first time: Imagined and experienced urban places. International Journal of Culture, Tourism, and Hospitality Research, vol. 11, no 3, pp. 321-340.

de Rosa A.S., Bocci E., Dryjanska L., 2017. Social representations of the European capitals and destination e-branding via multi-channel web communication. Journal of Destination Marketing \& Management, vol. 11, pp. 150-165.

DeREK M., 2018. Spatial structure of tourism in a city after transition: The case of Warsaw, Poland [in:] D. Müller, M. Więckowski (eds.), Tourism in transitions: Recovering decline, managing change, Cham: Springer, pp.157-173.

Diener A., Hagen J., 2013. From socialist to postsocialist cities: Narrating the nation through urban space. Nationalities Papers: The Journal of Nationalism and Ethnicity, vol. 41, no. 4, pp. 487-514.

Dudek A., 2005. Ślady PeeRelu: Ludzie, Wydarzenia, Mechanizmy (Wyd 3). Kraków, Arcana Instytut Historii PAN.

Durheim E., 1999 [1912]. The cultural logic of collective representations [in] C. Lemert (ed.) Social Theory: The multicultural and classic readings, Boulder, CO: Westview Press, pp. 89-99.

Dwyer O., Alderman D., 2008. Memorial landscapes: Analytic questions and metaphors. GeoJournal vol. 73, no. 3, pp. 165-178.

FOWKES R., 2002. The role of monumental sculpture in the construction of socialist space in Stalinist Hungary [in:] S. Reid, D. Crowley (eds.), Socialist spaces in Eastern Europe and the Soviet Union 1947-1991, London: Berg, pp. 65-85.

Giatzidis E., 2002. An introduction to post-communist Bulgaria: Political, economic and social transformation. Manchester: Manchester University Press.

Gorsuch A., 2003. There's no place like home: Soviet tourism in late Stalinism. Slavic Review, vol. 62, no. 4, pp. 760-785.

Gorsuch A., Koenker D., 2006. Turizm: The Russian and East European tourist under capitalism 
and socialism. Ithaca, NY: Cornell University Press.

Grandits H., TAYlOR K., 2010. Yugoslavia's sunny side: A history of tourism in socialism (1950s-1980s). Budapest: Central European University Press.

GRODACH C., 2002. Reconstituting identity and history in post-war Mostar, Bosnia-Herzegovina. City, vol.6, no.1, pp. 61-82.

Groys B., 2003. The art of totality [in:] E.A. Dobrenko, E. Naiman (eds.), The landscape of Stalinism: The art and ideology of Soviet space, Seattle and London: University of Washington Press, pp. 96-124.

HALL D., 1991. Tourism and economic development in Eastern Europe and the Soviet Union. London: Belhaven Press.

HaLL D., 2008. From 'bricklaying'to 'bricolage': Transition and tourism development in Central and Eastern Europe. Tourism Geographies, vol. 10, no.4, pp. 410-428.

Hamilton F.E.I., Dimitrovska Andrews K., Pichler-Milanovic N., 2005. Transformation of cities in Central and Eastern Europe: Towards globalization. Tokyo: United Nations University Press.

HölJER B., 2011. Social representations theory a new theory for media research. Nordicom Review, vol. 32, no. 2, pp. 3-16.

Hughes H., Allen D., Wasik D., 2003. European capital of culture and its significance for tourism and culture: The case of Krakow 2000. International Journal of Arts Management, vol. 5, no. 3, pp. 12-23.

IVANOV S., 2009. Opportunities for developing communist heritage tourism in Bulgaria. Turizam: znanstveno-stručni časopis, vol. 57, no.2, pp. 177-192.

JAAKSON R., 1996. Tourism in transition in post-Soviet Estonia. Annals of Tourism Research, vol. 23, no. 3, pp. 617-634.

Kaneva N., 2012. Nation branding in PostCommunist Europe: Identities, markets and democracy [in:] N. Kaneva (ed.), Branding postcommunist nations: Marketizing national identities in the "New" Europe, London: Routledge, pp. 3-23.

Kaneva N., Popescu D., 2011. National identity lite Nation branding in post-communist Romania and Bulgaria. International Journal of Cultural Studies, vol. 14, no. 2, pp. 191-207.

KIGLICS I., 2007. Rebuilding the market economy in central-east Europe and the Baltic countries. Budapest: Akademiai Kiad.

Koenker D., 2013. Club Red: Vacation travel and the Soviet Dream. Ithaca, NY: Cornell University Press.

KozYrSkA A., 2016. Decommunisation of the public space in post-Euromaidan Ukraine. Polish Political Science Yearbook, vol. 45, pp. 130-144.

Kramer M., 2011. The demise of the Soviet Bloc. Europe-Asia Studies, vol. 63, no.9, pp. 15351590.

LANKAUSKAS G., 2006. Sensuous (re)collections: The sight and taste of socialism at Grütas Statue Park, Lithuania. The Senses and Society, vol. 1, no. 1, pp. 27-52.

Light D., 2000a. An unwanted past: Contemporary tourism and the heritage of communism in Romania. International Journal of Heritage Studies, vol. 6, no. 2, pp. 145-160.

LIGHT D., 2000b. Gazing on communism: Heritage tourism and post-communist identities in Germany, Hungary and Romania, Tourism Geographies, vol. 2, no. 2, pp. 157-176.

LIGHT D., Young C., 2010. Reconfiguring socialist urban landscapes: The 'left-over' spaces of state-socialism in Bucharest. Human Geographies: Journal of Studies and Research in Human Geography, vol.4, no.1, pp.5-16.

LIGHT D., Young C., 2013. Urban space, political identity and the unwanted legacies of state socialism: Bucharest's problematic Centru Civic in the postsocialist era. Nationalities Papers: The Journal of Nationalism and Ethnicity vol. 41, no. 4, pp. 515-535.

Light D., Young C., Czepczyński M., 2009. Heritage tourism in Central and Eastern Europe [in:] D. Timothy, G. Nyaupane (eds.), Cultural heritage and tourism in the developing world: A regional perspective, London: Routledge, pp. 224-246.

Linz J., Stepan A., 1996. Problems of democratic transition and consolidation: Southern Europe, South America, and post-communist Europe, Baltimore, MD: The John Hopkins University Press.

LODDER C., 1993. Lenin's plan for monumental propaganda [in:] M. Bown, B. Taylor (eds.), Art 
of the Soviets, Manchester: Manchester University Press, pp. 16-32.

MACKenZIE B., 2011. Marketing of the dark: Memento Park in Budapest. Emerald Emerging Markets Case Studies, https://doi. org/10.1108/20450621111197604 [20 May 2019].

MarciszewsKa B., 2006. Tourism in Poland: Changes in policy, management and education [in:] D. Hall, M. Smith, B. Marciszewska (eds.), Tourism in the New Europe: The challenges and opportunities of EU enlargement, Wallingford: $C A B I$ Publishing, pp. 127-139.

Martens P., Rotmans J., 2005. Transitions in a globalising world. Futures, vol. 37, no. 10, pp. 11331144.

Moscovici S., 1988. Notes towards a description of social representations. European Journal of Social Psychology, vol. 18, pp. 211-250.

Moscovici S., 2000. Social representations: Explorations in social psychology. Cambridge: Polity Press.

Munasinghe H., 2005. The politics of the past: Constructing a national identity through heritage conservation. International Journal of Heritage Studies, vol. 11, no. 3, pp. 251-260.

MuRZYN M., 2008. Heritage transformation in Central \& Eastern Europe [in:] B. Graham \& P. Howard (eds.), The Ashgate research companion to heritage and identity, Aldershot: Ashgate Publishing, pp. 315-347.

MülleR D., 2018. Tourism and transition [in:] D. Müller, M. Więckowski, M. (eds.), Tourism in transitions: Recovering decline, managing change, Cham: Springer, pp.1-20.

MülleR D., WIĘCKOWSKI M., 2018. Tourism in transitions: Recovering decline, managing Change. Cham: Springer.

Naumov N., 2018. Geographies of transition: Heritage, tourism and identity in socialist and post-socialist Bulgaria. Department of Geography, King's College London, [Unpublished PhD thesis].

Oтто J., 2008. Representing communism: Discourses of heritage tourism and economic regeneration in Nowa Huta, Poland. University of Minnesota, Department of Geography [Unpublished PhD thesis].

Poria Y., Ivanov S., Webster C., 2014. Attitudes and willingness to donate towards heritage restoration: an exploratory study about Bulgarian socialist monuments. Journal of Heritage Tourism, vol. 9, no. 1, pp. 68-74.

PyzIK A., 2015. Warsaw's Palace of Culture, 'Stalin's gift': A history of cities in 50 buildings, day 32. The Guardian, available at: https://www. theguardian.com/cities/2015/may/08/warsawpalace-of-culture-stalin-a-history-of-cities-in50-buildings-day-32 [08 May 2015].

Rátz T., Smith M., MichalKó G., 2008. New places in old spaces: Mapping tourism and regeneration in Budapest. Tourism Geographies, vol. 10, no. 4, pp. 429-451.

Rosenbaum A., 2015. Leisure travel and real existing socialism: New research on tourism in the Soviet Union and communist Eastern Europe. Journal of Tourism History, vol.7, no.1-2, pp. 157176.

Sheppard E., 2000. Socialist cities?. Urban Geography, vol. 21, no. 8, pp. 758-763.

SidOROV D., 2000. National monumentalization and the politics of scale: The resurrections of the Cathedral of Christ the Savior in Moscow, Annals of the Association of American Geographers, vol. 90, no. 3, pp. 548-572.

SIMA C., 2017. Communist heritage representation gaps and disputes. International Journal of Tourism Cities, vol. 3, no. 3, pp. 210-226.

SMITH L., 2006. Uses of heritage. Abingdon, Oxford: Routledge.

Sparitis O., 2003. The rebirth and restoration of administrative, political and cultural symbols in Riga's Town Hall Square [in:] J. Czaplicka, B. Ruble (eds.), Composing urban history and the constitution of civic identities, Washington: Woodrow Wilson Center Press, pp. 341-371.

StANILOV K., 2007. The post-socialist city: Urban form and space transformations in Central and Eastern Europe after socialism. Dordrecht: Springer.

SWARBROOKE J., 2002. The development and management of visitor attractions. Oxford: Butterworth-Heinemann.

Szelenyl I., 1996. Cities under socialism - And after [in:] G. Andrusz (ed.), Cities after socialism: Urban and regional change and conflict in post-socialist societies, Malden, MA: Blackwell, pp. 286-317.

TILL K., 2004. Political landscapes [in:] J. Duncan, N. Johnson, R. Schein (eds.), A companion 
From Socialist icons to Post-Socialist attractions: Iconicity of socialist heritage...

to cultural Geography, Oxford: Blackwell Publishing, pp. 347-365.

TILL K., 2005. The new Berlin: Memory, politics, place. Minneapolis, Minnesota: University of Minnesota Press.

VERDERY K., 1996. What was socialism and what comes next? Princeton, NJ: Princeton University Press.

VuKov N., 2006. "Brotherly help" representations or "imperial" legacy: Monuments to the Soviet Army in Bulgaria before and after 1989. Ab Imperio, vol. 1, pp. 267-293.

VuKOV N., 2008. The "unmemorable" and the "unforgettable": Museumizing the socialist past in post-1989 Bulgaria [in:] P. Apor, O. Sarkisova (eds.), Past for the eyes: East European representations of socialism in cinema and museums after 1989, Budapest \& New York: CEU Press, pp. 307-335.

Vukov N., ToncheVA S., 2006. Town squares and socialist heritage: The reworking of memorial landscapes in post-socialist Bulgaria [in:] S. Schröder-Esch (ed.), Practical aspects of cultural heritage - Presentation, revaluation, development, Weimar: Bauhaus-Universitat, pp. 175-185.

Weidenfeld A., 2010. Iconicity and 'flagshipness' of tourist attractions. Annals of Tourism Research, vol. 37, no. 3, pp. 851-854.

Weidenfeld A., Butler R., Williams A., 2016. Visitor attractions and events: Locations and linkages. Abingdon, UK: Routledge.

Young C., Kaczmarek S., 2008. The socialist past and post-socialist urban identity in Central and Eastern Europe: The case of Łódź, Poland. European Urban and Regional Studies vol. 15, no. 1, pp. 53-70.

Young C., LIGHT D., 2001. Place, national identity and post-socialist transformations: An introduction. Political Geography, vol. 20, no. 8, pp. 941-955. 
